\title{
Irrigation Management Transfer and WUAs' dynamics: evidence from the South-Kazakhstan Province
}

\author{
Andrea Zinzani
}

Received: 14 June 2013/Accepted: 17 March 2014/Published online: 3 April 2014

(c) Springer-Verlag Berlin Heidelberg 2014

\begin{abstract}
Since the collapse of the Soviet Union, in Kazakhstan, as in the other Central Asian republics, significant changes in both the water and agricultural sectors have emerged; water management shifted from a purely technical issue to a sociopolitical and economic one leading to several institutional and organizational changes. To address this transitional context and its issues, since the 1990s international donors have supported the establishment of Irrigation Management Transfer (IMT) and the Water Users Associations (WUAs), both initiatives sponsored and related to the IWRM framework. This paper discusses these processes in the South-Kazakhstan Province, 10 years since the enactment of the law formalizing WUAs; three districts were selected for the analysis. The paper concludes that the IMT has been implemented in different and ambiguous methods and times, reflecting specific district dynamics and issues; furthermore, government support of IMT has decreased, leading to unexpected changes in its role in local water management and a reconsideration of the future scenario.
\end{abstract}

Keywords Water management - IMT · WUAs · Central Asia $\cdot$ Kazakhstan

A. Zinzani $(\bowtie)$

Department TESIS, University of Verona, Verona, Italy

e-mail: andreazinzani@yahoo.it; andrea.zinzani@unifr.ch

A. Zinzani

Department of Geosciences-Geography Unit, University of Fribourg, Fribourg, Switzerland

\author{
Abbreviations \\ IMT Irrigation Management Transfer \\ WUA Water Users Association \\ IWRM Integrated Water Resources Management \\ O\&M Operation and maintenance \\ ISF Irrigation service fee
}

\section{Introduction}

Since ancient times, Central Asia has been affected by water scarcity issues due to climatic and physical features; therefore, irrigation and water control have always played a significant role in territorial and societal development. The collapse of the USSR and the subsequent shift from Soviet state control to new independent republics strongly affected water processes, leading to several problems and lacks regarding both institutional/political and technical issues (Abdullaev and Mollinga 2010). In the Central Asian region, water management and allocation shifted from a purely technical issue, carried out by a state-centralized power, to a sociopolitical and economic one, strongly related with institutional changes, population growth, and food self-sufficiency (Abdullaev and Mollinga 2010). The irrigation systems in the Soviet Union were designed for large-scale farms and their dismantling and division into smaller units made water management less efficient and consequently increased potential conflicts over water among the farmers (Rakhmatullaev et al. 2013).

To address this transitional water management context and the related governance and technical lacks, starting from the mid-1990s several international organizations and donor agencies (such as the World Bank, United Nations, USAID, and others), according to the international water community, have sought to streamline the Irrigation 
Management Transfer (IMT) and the establishment of the Water Users Associations (WUAs). These processes can be considered part of the backbone of the Integrated Water Resources Management (IWRM) framework, a programme launched in Dublin in 1992 to promote sustainable societal and environmental development and has since become the worldwide water management paradigm for the third millennium (GWP 2009).

This paper aims to discuss those transitional water management processes, focusing on the meso/local level in the South-Kazakhstan Province, Kazakhstan. This province has been the most important irrigated agricultural area in Kazakhstan since the 1960s, due to the development of the Arys-Turkestan and Shaulder irrigation schemes. Thanks to these suitable conditions, since the mid-1990s the SouthKazakhstan Province, as claimed by Wegerich (2008), has received special attention and support from international donors through development projects, for the establishment of the WUAs. Within the province, three districts were selected, Tyulkibas, Ordabasy and Otrar, to analyse the specific local transitional water institutional/organizational framework and to highlight the differences among them. The fieldwork was conducted in two different phases, April-May and November-December 2012. Within those periods, interviews were carried out with the main stakeholders involved in meso/local level water processes such as staff and members of river basin agencies and district and province water departments as well as the WUAs' directors and members, and independent farmers. The analysis and data collection were conducted through semistructured interviews, informal conversations, focus groups and field-surveys, officially supported by the Auezova State University of Shymkent.

The paper continues with an overview of the framework of Irrigation Management Transfer and the establishment of the WUAs, topics recently debated by both European and Central Asian scholars, and with a brief review on their implementation in Central Asia. This is followed by a background analysis of the reforms carried out in Kazakhstan on land and water management since the 1990s, focusing in particular on the basin/meso level and on subsequent WUAs' institutional support and establishment. The sections following the background survey focus on the analysis of the field-research region; a geographical background of the Arys Valley, totally included in the SouthKazakhstan Province, will be pointed out before focusing in depth on the institutional and organizational water management issues within the districts. Finally, the results will be compared to evaluate the provincial water management context. Although the IWRM framework, Irrigation Management Transfer and the WUAs' support were formalized in the 2003 Water Code, the implementation path at the local level has occurred at different times and with ambiguous methods, reflecting specific district dynamics and issues. Overall, the evidence has shown that in the last years the government support to WUAs and generally to the IWRM pillars decreased, making the reform path for the future questionable and uncertain.

\section{Irrigation Management Transfer and WUAs in the Central Asian region: a framework overview}

Between the 1960s and the 1980s huge capital investments in the designs of large-scale public irrigation schemes have been carried out by centralized governments, in particular in countries such as the USSR or the People's Republic of China, where the state played a strong role in natural resources management as well as in territorial and societal development. In the mid-1980s it emerged that part of these investments, as is generally the case in developing countries, were not achieving the increases in productivity that were expected (Hunt 1989). Moreover, in some countries these huge hydraulic infrastructures started deteriorating due to lack of funds for operation and maintenance and to the poor quality of construction. MeinzenDick et al. (1994) added that many projects have incorporated engineering interventions without adequate consultation with local users and project designers, therefore lacking essential information about local conditions and needs. Significant governmental and political/economic changes occurred in several countries at the end of the 1980 s, that is, shifting from a planned economy to a market one, leaving those hydraulic infrastructures without an efficient management and control structure (Feike et al. 2013). According to Faggi (1991), focusing on Sahelian countries, a structural adjustment was necessary to improve the irrigation schemes' operation and maintenance $(\mathrm{O} \& \mathrm{M})$, transferring the management's control from the state departments to the local water users. Allan (2003) stated that these processes of water management decentralization were more complex in those developing countries characterized by state-centralized governments, part of them still involved in their hydraulic mission. In the last decades, many countries affected by political/economic transitions have reorganized or reformed their water sector; these reforms were oriented towards decreasing subsidies and focused on price-fixing schemes, capacity building, and the development of strategies and legal frameworks (Abdolvand et al. 2013a, b; Groll et al. 2013). Those management changes were supported by international donors and development banks which induced governments to co-manage the irrigation systems with the local users through an inclusive and participatory approach: the Irrigation Management Transfer (IMT) concept that several development projects have been based on. According to 
Ghazouani et al. (2012), the IMT refers to the process that seeks the relocation of responsibilities and authority from central governments entities managing irrigation schemes to non-governmental agencies such as the Water Users Associations (WUAs) or to private entities. Although most of the scholars stated that this process might lead to an increase in participation and inclusion in management processes by the water users, Yakubov and Ul-Hassan (2007) discussed that the participatory management may also lead to a discrepancy between the marginalized poor and powerful groups, appropriating the reforms' benefits. Ghazouani et al. (2012) and Mollinga (2007) claimed that those decentralization policies mean a neo-liberal approach, rolling back the role of the state in water resource management. It was also mentioned that the IMT would lead to benefits for governmental budgets, reducing governmental spending in irrigation systems' maintenance; Wegerich (2006) claimed that several governments, in particular those of transitional countries, as the former Soviet Union and Eastern Europe, could no longer maintain the subsidies for large irrigation schemes, being affected by financial crisis. The worldwide example of IMT, particularly in developing countries, has been the establishment of the Water Users Associations, defined by Salman (1997) as a group of farmers, usually with one hydraulic unit, command or irrigation district, organized as a non-profit organization for the purpose of managing partial or whole irrigation systems. According to Ghazouani et al. (2012), the established WUA should be structured on three domains of responsibility: water management, maintenance, and financial management. Through those domains the farmers should be able to participate in decision-making processes, planning water allocation schedules, maintaining the water facilities and the outlets, and collecting the fees for the WUAs' financial budget. Depending on several sociopolitical factors, different WUAs' variants have been established worldwide, in some cases including a formal governance council or only informal meetings, in other cases managing all the irrigation schemes or just the tertiary level. According to Salman (1997), an institutional framework and governmental support are needed for proper WUAs' performance; he mentions the enabling law, the bylaws of the WUAs and the transfer agreement between the irrigation agency (state agency or department) and the WUAs. Regarding the WUAs' establishment, its performance and sustainability, Wegerich (2006), reviewing the statement of several scholars (Meinzen-Dick et al. 1994, and others), claimed that the WUAs' performance is directly influenced by external and internal factors, complementary among each other. Focusing on the external factors, he mentions physical and technical, policy and governance, and social and economic; regarding the internal ones, the bylaws, structural organization, membership criteria and group dynamics. Therefore, it might be questioned whether those concepts, mostly developed by the Western water community within the support of the wider IWRM framework, could be efficiently implemented in developing countries and in particular in those still characterized by a state-centralized approach in natural resource management.

Focusing on the Central Asian republics, according to DFID (2003), although more than 10 years have elapsed since independence, the effects of the move to a market economy are still in progress, in different time frames and ways depending on the countries, their political, economic and social systems. Furthermore, he argued that historical and social context are particularly relevant when considering an IMT program in Central Asia; they mentioned several issues ranging from the transitional political-economic environment and the considerable bureaucracy of the still working top-down command structures in state administration. Although with significant differences, IMT processes in the Central Asian republics have been supported by international donors since the mid-1990s, while on average in the whole region the dismantling process of the state and collective farms was ongoing. According to several scholars, the relevancy of IMT implementation was founded on two main issues: firstly, the rise of independent peasant farmers and the need for an efficient and fair water management and allocation; secondly, the financial conditions of the governments, which were not able to ensure the operation and maintenance of the large irrigation systems (Abdullaev and Rakhmatullaev 2013; Wegerich 2006; DFID 2003; Sehring 2007; Abdullaev and Mollinga 2010; Bichsel 2009). The development banks' actions to promote the creation of WUAs have been strictly related with the sociopolitical issues mentioned by DFID (2003): the IMT processes occurred more rapidly in the countries where the institutional-political environment was more suitable for those changes. In Kirghizstan, due to the government's collaborative approach towards the aid agencies (World Bank and Asian Development Bank), the legal framework supporting the WUAs' establishment was already issued in 1997 (Sehring 2007; Rost et al. 2013). Comparatively, in Tajikistan the IMT processes were partly hampered by the civil war and the subsequent governmental fragmentation and by the deteriorated status of the water facilities (Gunchinmaa and Yakubov 2009). A different sociopolitical context has hampered the international agencies' development plans both in Turkmenistan and Uzbekistan, where agricultural reforms were not completely based on market principles, keeping the state quotas for the main crops (Aminova and Abdullaev 2009). Although the WUAs were finally established between 2003 and 2007, their performance has been partly influenced by an inappropriate legal framework and by the state's still influential role in water resources management, which has 
limited the farmers' empowerment and the creation of governance structures (Abdullaev and Rakhmatullaev 2013). The water reform path and IMT processes in Kazakhstan will be further analysed below.

\section{Background: water management reforms in Kazakhstan}

Reforms of state-led water management in Kazakhstan have followed the land reforms that have been conducted since 1992 in two steps: the first one, which occurred between 1992 and 1997, addressed the transformation of the former state and collective farms into production cooperatives and collective enterprises (Wegerich 2008). According to Burger (1998), in early 1996, 93 \% of Kazakhstan's state and collective farms had been privatized and re-registered as private entities. This reform phase was strengthened through the enactment of the Land Code (1995) which allows farmers to lease an agricultural plot, ranging from 5 to 15 ha, from the state on a long-term basis (99 years); furthermore, the market liberalization has been significantly supported through the abolishment of state quotas for crops (Pomfret 2007). The first measure on water management issued after independence was the Water Code (1993), which has not led to any significant changes at meso/local level; this law does not express any reference to the IMT processes, stating that water management is executed by state departments and agencies.

The second step of agricultural reform has been carried out since 1998 through the enactment of the bankruptcy law which defined the practical application of bankruptcy to the farm sector; the large cooperatives enterprises were totally dismantled, significantly increasing the rise of private farmers. Though, according to Burger (1998), in 1996 the number of private entities in the agricultural sector was on average 6,000, Wegerich (2008) stated that in 1999 it reached an average of 90,000. Therefore, although the agricultural reforms started in 1992, the evidence shows that they were completely implemented by the end of the 1990s. Although in that decade water management and allocation at the meso/local level was conducted by the District water departments for state and collective farms, after the rise of peasant farming those state administrations were unable to cope with the thousands of new independent water users. Furthermore the District water departments were affected both by technical and financial shortages; some of them were transferred from the state authorities' supervision to the local government (Akimyat) (Zimina 2003). At the province/basin level, the water management structure resulted in a more stable and structured system compared to the district one; the River Basin Agencies (BWO) based on basin principles and the Republican State
Enterprises (RGP-formerly called Province Water Departments) based on province boundaries are responsible for monitoring water allocations and facilities. Their separated tasks were decided through a decree, issued in 1996.

Regarding the changing and weak context at the local level, as Burger (1998) claimed, in 1996 the Kazakh government already had launched a programme of public tenders to support the creation of associations of water users without achieving any significant results; in 1997 a guidebook including all the information regarding the WUAs' establishment was provided by the government to the farmers trying to cope with water management lacks and to strengthen the reforms (Burger 1998).

Different perspectives among the scholars have emerged concerning when the first WUAs started operating in Kazakhstan; according to Wegerich (2008), there were misinterpretations about the formal and informal status of the WUAs and about who had member status. While Zimina (2003) argued that the first WUAs in Kazakhstan were already established in 1993, an association of water users without a formal organization, DFID (2003), stated that the WUAs have been working in some areas since 1996. Nevertheless, it should be underlined that the WUAs' establishment in that period, (1996-1998), coincided with the creation of a local development project led by the international donors, the World Bank, Asian Development Bank, and USAID, supporting the formalization of IMT and the restructuring of water facilities. Credits and financial aid were provided to the farmers, often the members of the former collective farms, to establish a WUA with an organizational structure. Furthermore, following socio-environmental sustainability, in 1997 water fees for agricultural water users were introduced, calculating the water use by cubic metre. Nevertheless, because the irrigation schemes were built for large collective farms, often water consumption is just estimated rather than measured, leading to inequities and abuses among the farmers (Wegerich 2008). In addition, a WUA is not able to work fairly without an appropriate legal framework that institutionalizes its status and responsibilities, and supervises its management and governance. Recognizing the inadequacy of the 1993 Water Code to strengthen the reforms oriented to the IMT, the government of Kazakhstan, with the support of the UNDP, enacted a new Water Code in July 2003; through this measure the IWRM framework was formalized as the strategical pattern for future development in the water and environmental sector (Janusz-Pawletta 2013). Following this perspective, that same year Law n. 404-11 was issued by the Cabinet of Ministries of Kazakhstan, which institutionalized the existing WUAs as the Rural Consumers Cooperatives of Water Users (SPKV) providing an official status to the associations (Ghazouani et al. 2012). According to the enacted law, the WUAs have to register as non- 
profit organizations in the district justice department specifying the director, members, and its functions. Regarding their territory, despite that ones based on hydrographic principles were supported, Kazakh WUAs refer both to administrative boundaries, as former collective farms and district ones, as well as hydrographic ones, covering on average 1,500-2,500 ha; in most cases the established WUAs refer to the old state or collective farm boundaries. As highlighted in the enacted law, the WUAs are responsible for their operation and maintenance (O\&M), hence water allocation to the farmers and maintenance of the irrigation facilities at the tertiary and secondary levels through water fee collection have been adopted; secondary canals are leased from the District water departments. As Salman (1997) stated, autonomous irrigation agencies such as WUAs should provide better services to their users, promoting governance and providing a fair share of water in a timely manner. Nevertheless, Wegerich claimed that the Law of 2003 left unclear how the governance structure should operate and did not specify how to effect its separation from the management (Wegerich 2008). Although hundreds of WUAs have been established and formalized since 2003, depending on the development projects' and on the farmers' organizational and financial availability, at the local level the District water departments continued operating, providing water to the farmers not involved in the WUAs. Focusing on the Machtaral and Otrar districts, both in South-Kazakhstan Province, evidence has shown how the action of the international donors, working in Machtaral since 1997, facilitated the establishment of the WUAs and the strengthening of IMT leading to a decrease of the District water department's role; the context significantly differs in the Otrar District where no projects were created and the creation of WUAs seemed more challenging. Nevertheless, it is important to underline the challenging process that emerged between the WUAs' establishment and their effective performance. Both Zimina (2003) and Wegerich (2008) claim that several WUAs did not work fairly, and some of them failed in their organizational structure due to strong political influences by local state actors and lack of bottom-up support from the farmers; moreover, the IMT has been ill-planned and the withdrawal of the state too rapid, without considering local realities (Zimina 2003; Wegerich 2008). On the other hand, analysing the state and districts authorities, experts from the Republican State Enterprise (RGP-Iujvodkhoz) stated that due to lack of financial availability, the District water departments will be soon totally dismantled. This process will lead to substantial changes in local water management that will have to be analysed (personal communication with Iujvodkhoz members, May 2012). To address and understand those issues at the local level, data from the three districts are presented in the next paragraphs.

\section{Arys Valley: a geographical background}

The Arys Valley, one of the most important agricultural areas of Kazakhstan, lies in the southern part of the country and is entirely included in South-Kazakhstan Province that neighbours Uzbekistan (Fig. 1). The Arys River, (average runoff $46 \mathrm{M} 3 / \mathrm{s}$ and total length $378 \mathrm{~km}$ ) originates in the Ugamskii-Talaskii Alatau mountains, which is part of the western Tian-Shan range (Tiulkibas District) and flows in the W/NW direction until its confluence in Syr-Darja River, not far from Shaulder village in Otrar District. The basin catchment covers $14,000 \mathrm{~km}^{2}$, while the total irrigated area is $170,000 \mathrm{ha}$; the major part of the command area lies in the central downstream valley, while in the upper and middle section of the river irrigated lands are located only on its branches (width ranges between 5 and $15 \mathrm{~km}$ ), because in this area no irrigation schemes have been developed due to the physical features (hills and mountains) and there is the possibility to conduct rain-fed agriculture (annual average rainfall $350-400 \mathrm{~mm}$ ). Therefore, the central downstream section of the valley has been the part affected by the construction of hydraulic infrastructures and subsequent territory transformations carried out in the Soviet Union during the 1950s. In the Arys' midstream right bank, the Arys canal arises from the river and after $20 \mathrm{~km}$ flows into the Bogun reservoir, built for water storage during the winter and to release the water at the beginning of the cropping season. From this huge infrastructure, which can store 370 million M3 of water, arises the Arys-Turkenstan canal (ATK), built during the 1950s and characterized by an average flow rate of $40 \mathrm{M} 3 / \mathrm{s}$; the canal has a total length of $92 \mathrm{~km}$ and irrigates 55,000 ha in total, surrounded by the steppe, through an irrigation scheme of 55 secondary canals (average length $10-15 \mathrm{~km}$ ) arising from the ATK's outlets. In the downstream part of the Arys Valley a second irrigation scheme was built during the Soviet Union; a canal network (Kokmardan, Altimbekov and Shaulder canals), irrigating on average 35,000 ha arises from the Shaulder dam, which lies $25 \mathrm{~km}$ NW the Arys' confluence into the Syr-darja. Along the valley the most cultivated crops are wheat, fodder, and cotton. Focusing on the water management at the province level, responsibilities are divided, according to the decree of 1996, among the Aral-Syr-Darja River Basin Agency (BWO, including South-Kazakhstan and Kizylorda provinces) and the Republican State Enterprise-Iujvodkhoz. The $B W O$ is responsible for monitoring water use, consumption and quality, and fixing water quotas to the provincial bodies; in contrast Iujvodkhoz controls the main canals and reservoir of the province and is responsible for water allocation to the local level actors, District water departments and WUAs. The relations and issues among those organizations will be outlined in the three districts 
Fig. 1 GIS elaboration of an overlap of satellite images representing the Arys Valley, the river and the main canals of the irrigation system; (source: author)
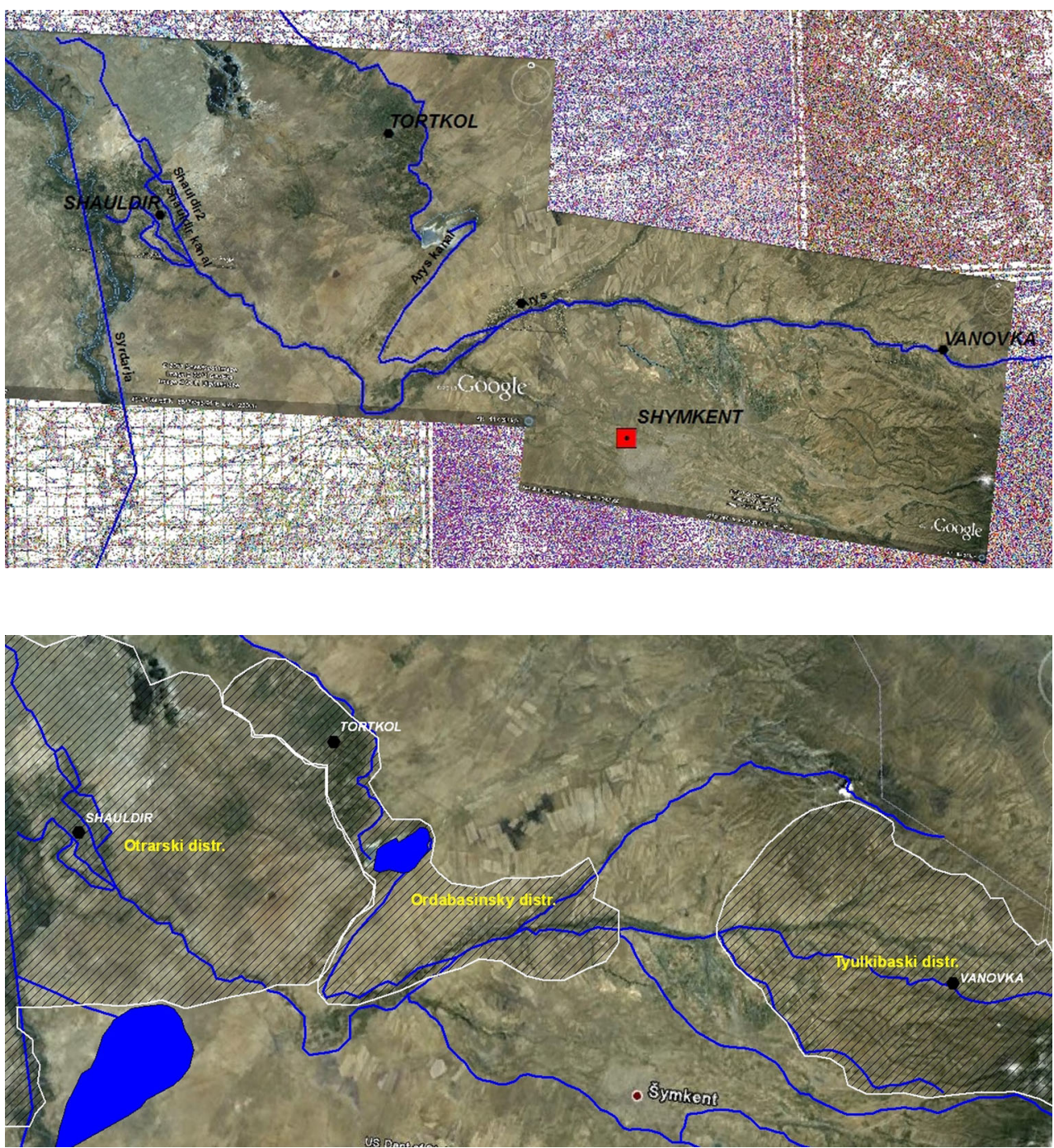

Fig. 2 GIS elaboration of a satellite image (source Google Earth) representing the Arys River, flowing from the $\mathrm{E}$ to the $\mathrm{W}$, and the three analysed districts chosen for analysis: Tyulkibas, lying in upstream valley, Ordabasy in the mid-stream section and crossed by both Arys and Arys-Turkestan canals and Otrar, located in downstream Arys Valley, characterized by Shaulder's irrigation scheme (Fig. 2).

\section{IMT in South-Kazakhstan Province: evidence from the districts}

According to interviewed experts of the Iujvodkhoz and of the state enterprise "IujnoKazakhstanskaja Gidrogeologa Meliorativnaja Expedizija", in South-Kazakhstan Province, despite national support to IMT for 10 years, there remains substantial differences and contrasts regarding its implementation among the districts, due to local issues and realities.

The Tyulkibas District lies in the upstream section of the Arys Valley, in the eastern part of the South-
Kazakhstan Province, $60 \mathrm{~km}$ north-east of Shymkent; the river flows in an $\mathrm{E}-\mathrm{W}$ direction at an altitude ranging from 1,200 to $650 \mathrm{~m}$ a.s.1.

The district irrigated area, mostly located in the centre of the valley on the Arys River's branches, reaches totally 17,000 ha and it is characterized by a small secondary canal networks; the most cultivated crops are wheat, fruit and corn (Fig. 3).

Despite the passage of the 2003 law on WUAs ( $S P K V$ ), in the administrative unit water management and allocation have been carried out by the District water department based on administrative boundaries. Water users interviewed in Vanovka (the district's chief town) stated that they knew about the WUAs' creation in Kazakhstan, but any measures by the district government have been enacted to support these institutional changes in the last years (personal communication with the farmers, Vanovka, April 2012). In 2010 the Tyulkibas District water department declared bankruptcy because of financial and organizational issues: a considerable decrease in the district budget (already reduced when 


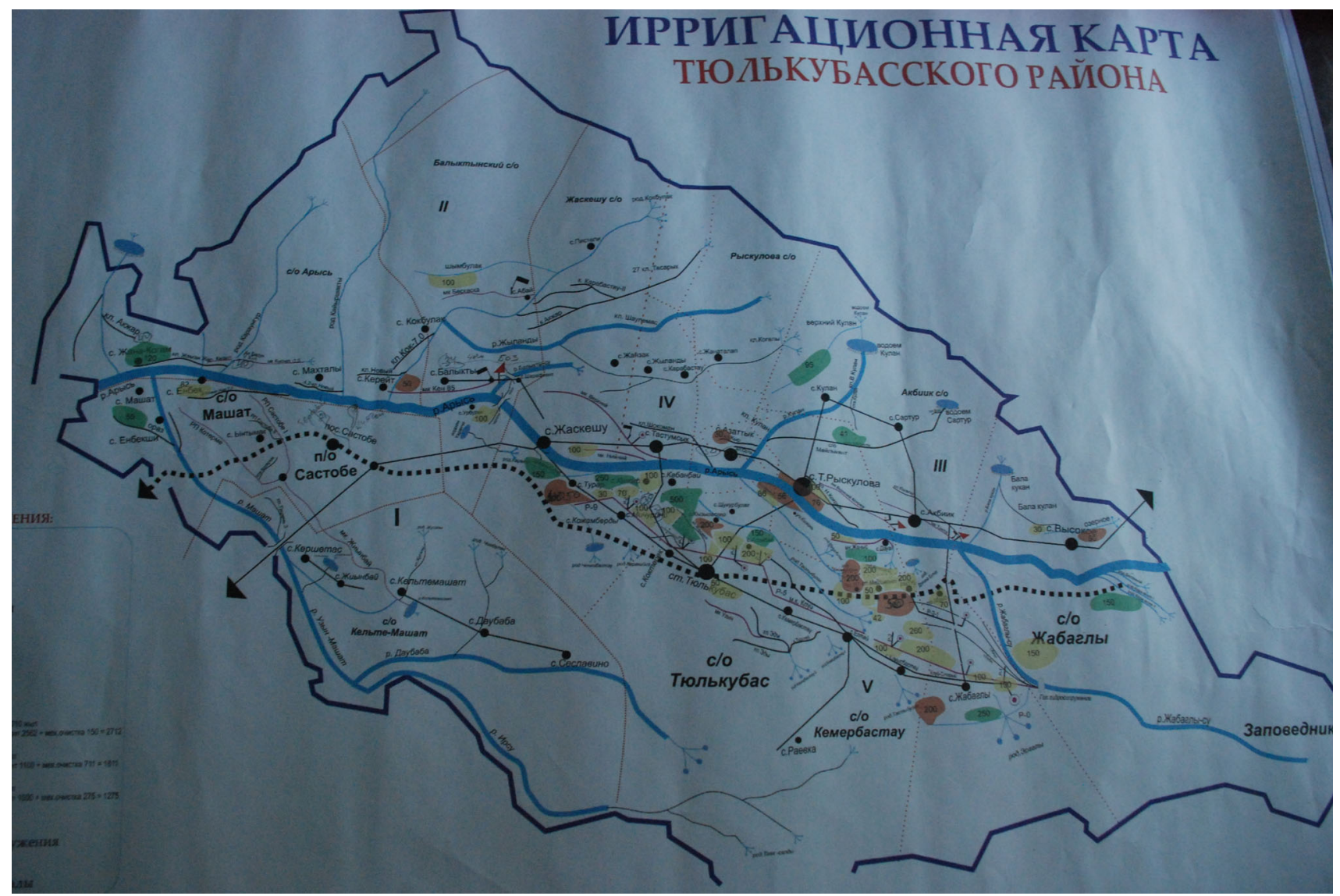

Fig. 3 Irrigation map of the Tyulkibas District (source: Tyulkibas WUA)

the state stopped financing district water departments), a small amount of water fees collected from the users and lack of technical staff to control and maintain the water facilities. Therefore, the association was reorganized in February 2011 and shifted its status to a WUA ( $S P K V$ ); the Tiulkibas WUA was registered in the District Justice Department and, having received authorization, it leased from the district government (Akimyat) the secondary canals' network. Despite the institutional shift, no changes occurred in either organization or maintenance; the head of the WUA is the director of the former water department, the staff (an accountant a hydro technician and seasonal miraab) has not changed, the water users have not been involved in WUAs' organization, and canals were not maintained despite an increase in irrigation fee. The WUA worked fairly only in 2011 although it has been affected by financial problems due to the water users' unwillingness to pay increased water charges. Farmers in Tyulkibas village stated that it does not make sense to pay fees to the WUA if it is not able to provide maintenance for the canals and fair water allocation (personal communication with the farmers, Tyulkibas, April 2012).

According to the WUA director, in 2012 most of the miraab could not be paid due to lack of financial resources and, therefore, no maintenance was carried out. Though the WUAs contract with the Justice Department was supposed to end in 2013, in October 2012 the Tyulkibas WUA finally stopped operating. Beside the financial issues (that is, no state support and lack of WUA budget), the director mentioned a significant lack of technical specialists and equipment as well as the inability to work following common objectives (personal communication with WUA director, Nov. 2012). The failure of the WUA led to an institutional and organizational void in the Tyulkibas District's water management; the district court will decide which organization will control the canals and provide water allocation. According to the WUA director, if a new WUA is not established by the farmers, water management will be given back to the district government. Hence, one strategy could be the reorganization of the district water department, despite the same financial, technical, and organizational issues that led to its bankruptcy in 2011. According to Iujvodkhoz members, the water context and IMT process for the immediate future in Tyulkibas District remains doubtful and unclear.

Moving to the second case study, the Ordabasy District lies almost in the centre of South-Kazakhstan Province in the Arys Valley middle stream. The district's irrigated area reaches a total of 32,000 ha; most of it is supplied by the irrigation system of Arys-Turkestan canal, connected with 
the Bogun reservoir, and by the Karaspan and Kulun canals. Though, as mentioned in the previous section, the main canals are under the jurisdiction of the Iujvodkhoz, the secondary ones arising from the ATK are the property of the district government (Akimyat) and most of them are managed by the Ordabasy District water department. If in the Tyulkibas district the IMT process has been marked by a failed shift of responsibilities from district department to the WUA, in Ordabasy the situation appears more complex. Although different WUAs have been formalized since 2004, both the district water department and Iujvodkhoz have been involved in water management and allocation.

The district water department has been affected by staff changes in the last years, due to the retirement of the head as well as by senior members, and today it confronts a lack of technicians and experts. Furthermore, the district's financial resources are not enough to deal with operational and maintenance expenses as well as staff pay. Though until 2005 the Ordabasy District water department managed the whole secondary canals' network and ensured water allocation for the entire district's irrigated land (excluding lands close to the main canals), today, after the WUAs' formalization, it controls on average 23-25,000 ha.

Conflicting opinions emerged regarding the current status of the District water department: although both the director and the head of the District Agricultural Department (Rayselkhoz) stated that, despite lacks, they are carrying out their tasks, the Iujvodkhoz members affirmed that, due to the financial shortage in the district budget, probably the authority will be dismantled in 2013. In contrast with the IMT's support and strength, the secondary canals probably will be supervised by the RGP Iujvodkhoz, and funded by the state budget (personal communication with RGP Iujvodkhoz Bogun branch, November 2012). Newly established WUAs could be responsible for those infrastructures, but the governor of the Ordabasy District (Akim) claimed that for the water users, the WUAs' creation process is very challenging, due to technical and financial issues and recent failures; therefore, the idea of giving back those tasks to state control prevailed (personal communication with RGP, December 2012).

Since 2004 three WUAs were established in the Ordabasy District: Karaspan WUA, Altursu WUA and Halik WUA; in total the irrigated area under their control reaches 8,000 ha, which on average is $25 \%$ of the district (Fig. 4).

As already analysed in the Tiulkibas District, no development projects were set up in the Ordabasy administrative unit by international donors to support IMT processes and the WUAs' establishment, as for instance occurred in the Machtaral District in the southern part of the province.

Karaspan WUAs were set up in 2005 by the former Karaspan sovkhoz hydro technician and his son. Its

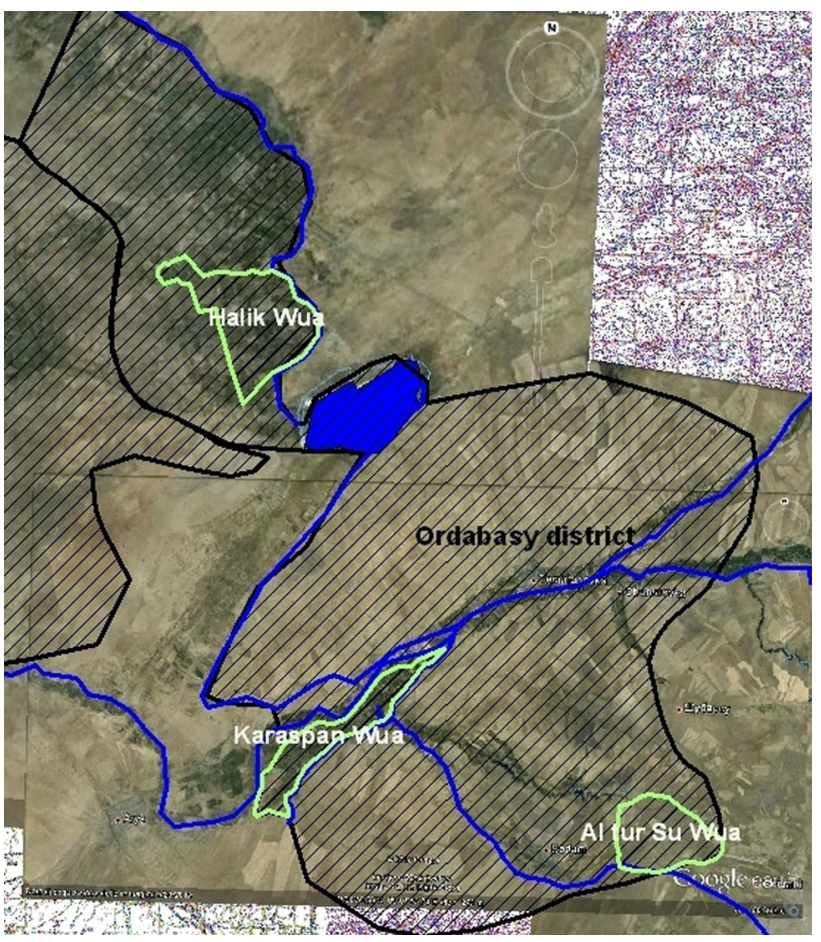

Fig. 4 GIS elaboration of a satellite image (Google Earth) representing the Ordabasy District, its irrigation scheme, and the established WUAs' territories; (source: author)

irrigated area reaches 4,265 ha, including two former sovkhoz, and it is supplied through 18 secondary canals arising from the Karaspan main canal $(24 \mathrm{~km}-7 \mathrm{M} 3 / \mathrm{s}$ connected to Arys River). Those canals, owned by the district government, are leased from the district water department for 5 years. According to the WUAs' staff and the farmers interviewed, water management and allocation significantly improved in the last year; farmers now receive water according to time schedules and thanks to the water charges (350 tenge/1,000 M3 -2.2 \$-) collected, new hydro-posts were recently installed by the WUAs' staff between secondary and tertiary canals. Furthermore, nine of those canals will have been restored during 2013. Despite these technical improvements, focusing on the governance, the evidence has shown that the organizational structure is quite weak: the WUA does not have elected assemblies or farmers' representatives, but just organizes councils twice a year to discuss water distribution and agricultural features. No elections have ever been organized for the WUAs' leadership. Nevertheless it is necessary to note that the Karaspan WUA, in contrast with the other associations, can rely on the knowledge and the experience, both technical and financial, of its staff: the accountant worked in the sovkhoz administration and the young director is the son of the first hydro technician of the former Karaspan sovkhoz, who today is employed in the Bogun branch of the RGP Iujvodkhoz (personal 
communication with RGP members, November 2012). The Altursuu WUA, established in 2004, shares similar features with Karaspan, even if it is not physically related to the Arys-Turkestanki canal system, but to Guldriuk main canal, arising from Badam River; twelve secondary canals, contracted by the WUA from the Ordabasy District water department are linked to the main canal, irrigating a total of 1,200 ha, in the territory of the former sovkhoz. As emerged in the Karaspan WUA, both the governance and the organizational structure are weak and still far from the IMT participation principles nationally promoted by the international donors. Although the main staff organizes councils twice a year involving twelve farmers, water users' representatives, the director, WUA founder and head of the organization for 8 years, stated that the irrigation practices and the maintenance of the canals has generally improved since 2004, so in the near future there will not be any changes regarding his position and the WUA staff. Furthermore, the Altursuu director added that financial resources, fair management practices and technical knowledge allows his WUA to work properly, but at the same time in the Ordabasy District other associations did not possess those qualities and failed. The third association, Halik WUA, established in 2011 and linked to the ArysTurkestan canal, is based on the hydrographic/administrative boundaries of the former sovkhoz. According to the director of the Jenis village, land office, Halik WUA was established to address the mismanagement and lacks of the Ordabasy District water department regarding the secondary canals' maintenance and water allocation. In the last 2 years, with financial resources acquired through fee collection, they were able to start the maintenance of the secondary canals and hydro-posts. The interviewed farmers claimed that for some years it has been very hard to deal with the district water department, because of their lacks and neglects in water allocation. Moreover, they added that the WUAs' formalization was possible thanks to the organizational and technical skills of the heads who worked in the sovkhoz.

The IMT process has not involved the farmers who are engaged with the lands lying close to Arys and the ArysTurkestan canals; since no secondary canals have to be managed and maintained, those farmers request water directly from the Iujvodkhoz Bogun branch. In addition, they have never worked with District water department and in the last 10 years no WUAs have been established (personal communication with Iujvodkhoz members, December 2012). According to the head of the Iujvodkhoz Bogun branch, those farmers have more certainty regarding water allocation procedures, as they are involved with a state enterprise; furthermore, he added that the farmers avoided all the mismanagement and lacks related to the district water department's financial and operational shortages and the problematic and challenging WUAs' establishment process.

The Otrar District lies in the downstream part of the Arys Valley mostly featured by steppes and deserts; a small area $(16,000 \mathrm{ha})$ is under irrigated agriculture, due to a system of canals, built from the 1950s to the 1970s, arising from the river, few kilometres upstream from the Arys' confluence into the Syr-darja. In the northern part of the district lies another command area, Aktyube-Celik, of 4,500 ha, supplied by the Bogun River, a natural watercourse regulated upstream by the Bogun reservoir (Fig. 5).

The evidence shows that in the Otrar District the IMT process is progressing differently compared to both Tyulkibas and Ordabasy; nowadays, only one WUA is working while the rest of the water facilities are under the district water department's control. According to the director, although until 2011 water shortage issues occurred, being at the tail end of the river and due to the facilities' conditions, during the winter of 2011/2012 the Altymbek canal and part of the secondary canals were restored with funds from the province's budget: new hydroposts were installed improving the accuracy of water measurements and the supply was adequate (personal communication with Otrar District's water department director, November 2012). Although the staff stated that the water department works fairly and is able to provide equal water allocation to the farmers, this statement was debated by several water users. According to small-medium plots owners (7-15 ha), the water department does not respect time schedules, some miraab do not work, and water supply inequities are widespread among small and large farmers; furthermore some of them receive benefits, being in close or familiar relations with the district's authorities (personal communication with the farmers, Shaulder village, April 2012).

Since 2003, when the WUAs' law was enacted, two WUAs were established (in 2008), but after 2 years they were dismantled due to lack of financial, organizational, and technical skills; According to the district water department director, the WUAs did not have adequate financial resources to support themselves and to carry out operation and maintenance. Moreover, some farmers interviewed confirmed that water fees increased since the WUAs have been operating without considerable improvements; hence, they affirmed their preference for dealing with the district water authority (personal communications with the farmers, Shaulder, April 2012).

As evident in the other districts, future water policies are unclear and unstable, as in Otrar as well; the IMT process has not been completed and not properly supported and the district departments are in flux.

Although no information on the current district financial budget for water management was locally released, 
Fig. 5 GIS elaboration of a satellite image (Google Earth) representing the Otrar District and Shaulder irrigation scheme; (source: author)

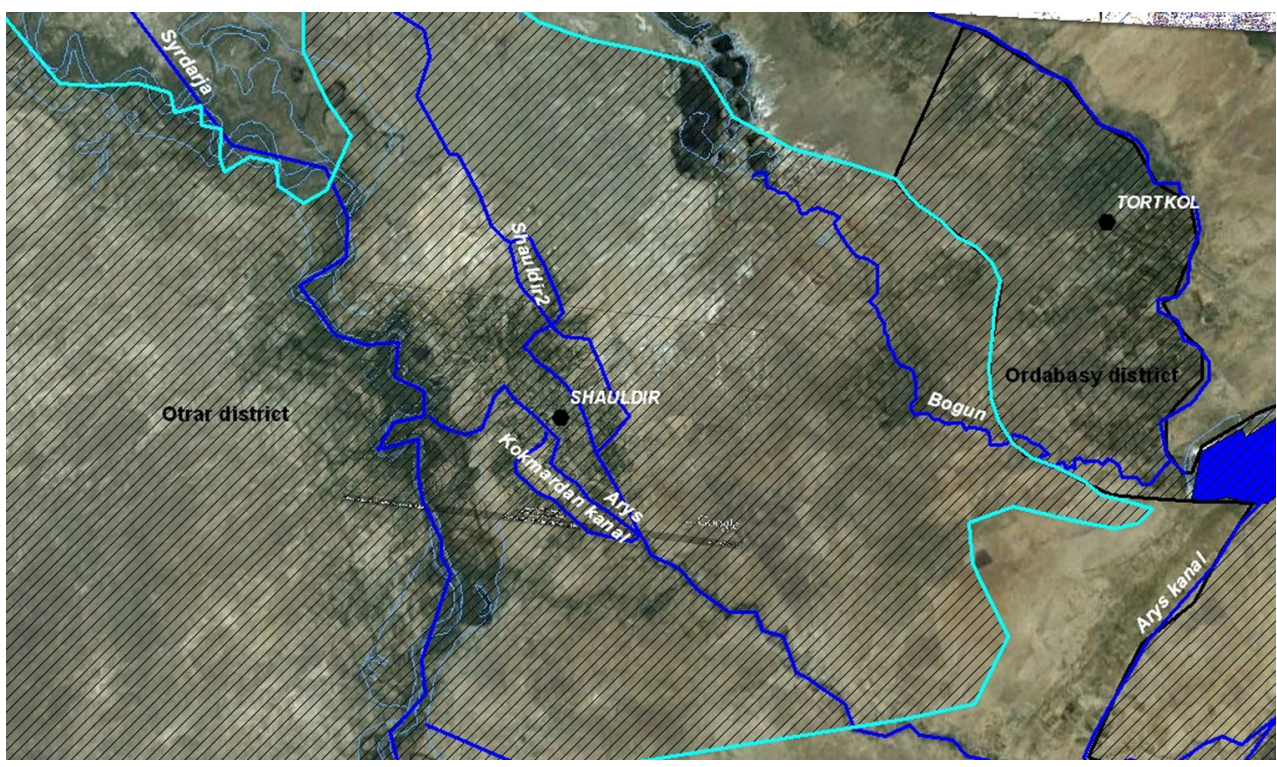

RGP Iujvodkhoz members affirmed that the district authority (Rayonnogo akimyat) was no longer able to fund the District water department's operations. Therefore, the secondary canals probably will soon be under the jurisdiction of the RGP Iujvodkhoz. According to their members the state budget for water infrastructures nationally increased in the last 2 years; hence the management's shift could be easily conducted. As pointed out in Ordabasy District, the hypothesis that new WUAs would be established has been recently challenged since there has not been enough support shown by both the district water department and most of the water users. As mentioned above, only one WUA, named Mahambet, is nowadays working, since 2007, in the northern part of the district, supplied by the Bogun River. Due to this main water course, Mahambet WUA has been operating since the end of the 1990s, when it was founded as an informal water users association $(A V)$, in connection with the RGP's Bogun branch instead of the district water department. Based on the Aktyube sovkhoz administrative unit, 2,500 ha, the WUA staff includes only the director and three miraab; the director also works as the accountant and hydro technician, having gained these competencies working as the head of Aktyube sovkhoz during the Soviet Union time (Fig. 6).

The farmers interviewed stated that here water allocation is better conducted compared to the Shaulder area; the number of farmers is lower and though an adequate governance system with a participative approach has not been set up, the WUA generally complies with its commitments.

According to the Aktyube village's land office, the Otrar District water department's members, despite its analysed issues, recently asked the dismantling of Mahambet WUA and the termination of the secondary canals' leasing contract. The request, clearly considered as a dispute between the district's department and the WUAs, was refused by the Mahambet director and it has emerged that the disputes will be addressed by the Otrar District court and by the RGP Iujvodkhoz. Therefore, no certainty has emerged about the next management's processes (Fig. 7).

\section{Discussion and conclusions}

Although the IMT process in Kazakhstan has been supported and formalized at the national level for 10 years (2003), at the local/district level the evidence shows that this process is significantly influenced by local dynamics, both from political and socio-economic perspectives, as well as by the physical environment. Focusing on the case studies, differences and discrepancies emerged: on the one hand, the IMT process and WUAs' formalization have been conducted according to different time frames and implementation procedures, while on the other hand it is possible to outline a homogeneous trend characterized by a weakness of the established organizations and by a reconsideration of the ongoing transition processes. Focusing on the district water departments, evidence shows that in all the analysed districts these authorities are now facing significant financial shortages due to political measure at the national level oriented to a reduction in the districts' budget. Though in Ordabasy and Otrar the departments are still able to operate, the department in Tyulkibas closed in 2011; the reasons behind this failure are connected both with the physical and political environment. Since in this upstream district, irrigation has been playing a less significant role due to the importance of rainfed agriculture and the absence of extended canal systems 

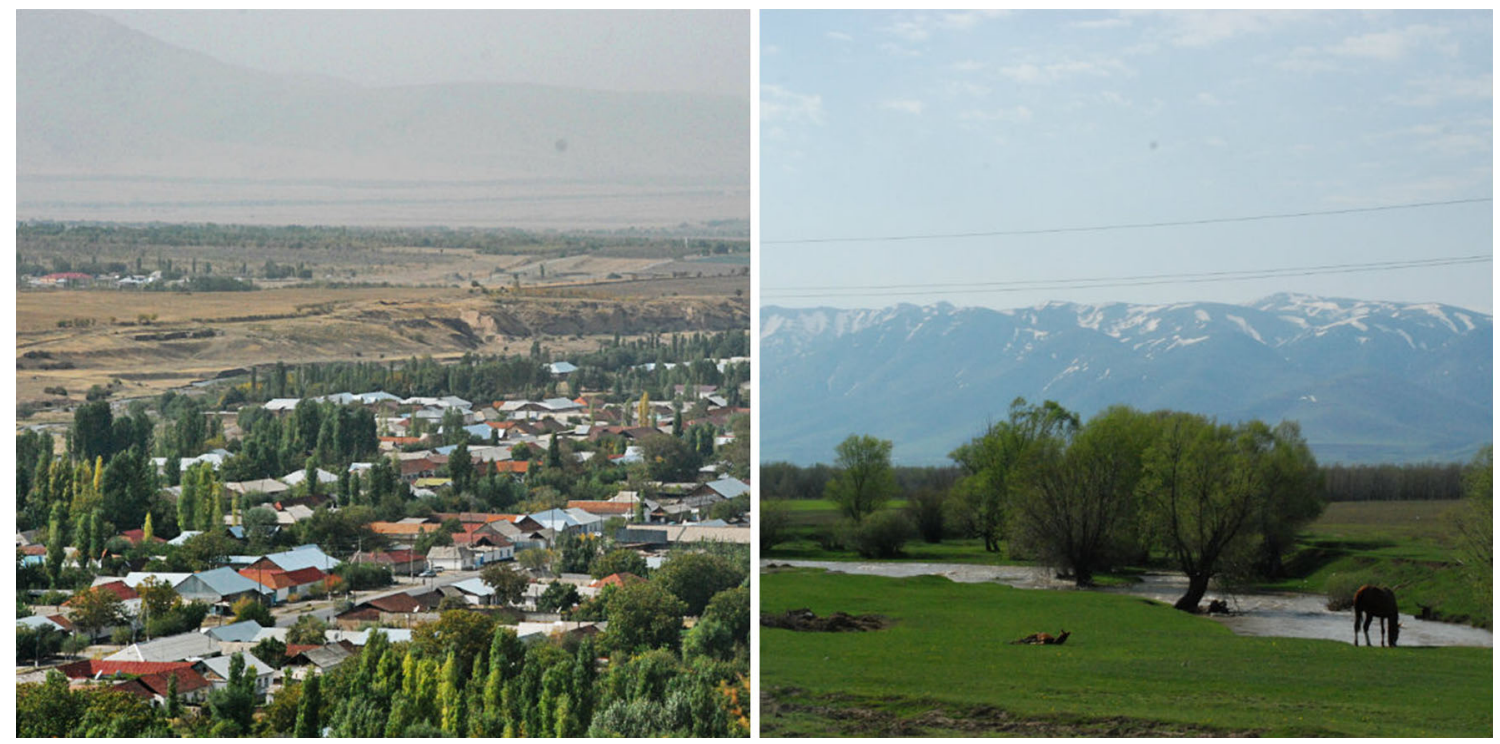

Fig. 6 Picture of upstream Arys Valley: Tyulkibas village (left), Arys River (right)
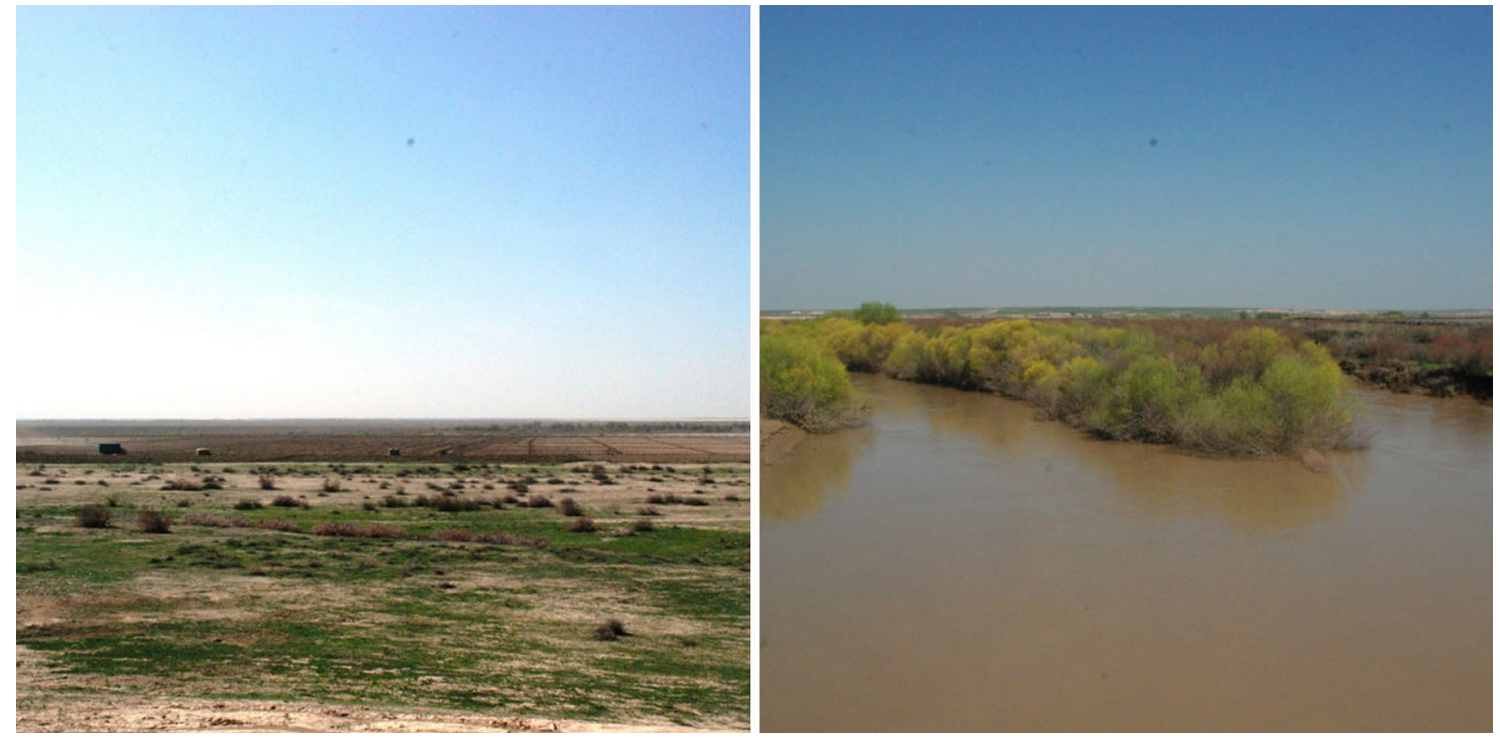

Fig. 7 Picture of downstream Arys Valley: Shauldir Province (left), Arys River (right)

in comparison with other administrative entities, the local members of the water department had less hydro-technical knowledge and capacities. In addition, the district budget allocated to the water department in these years was lower in comparison to those of Ordabasy and Otrar. For the same reasons, particularly regarding technical capacities, the WUA in Tyulkibas also failed in 2012, after only 1 year. Although during the first years after the passage of 2003 law, the IMT process seemed to be successfully completed, with the new water users organizations fairly operating, in the last years several issues have emerged: data analysis has shown that the WUAs' organizational framework and its performance is strictly connected with financial, political, and technical capacities on the local levels. The entities managed by the heads of the former sovkhoz (Karaspan, Altursuu, Aktyube WUAs in the Ordabasy District and Mahambet in the Otrar District) are able to operate, making the IMT apparently successful, while the WUAs that are lacking in these areas are not able to strengthen the organization and consequently failed. This trend is quite homogeneous, without significant differences between the Ordabasy and Otrar districts; in Ordabasy more WUAs are currently working due to the more extensive irrigated area; in this case political issues do not 
seem relevant. Furthermore, data outlined that the IMT in this region has not reached its aims; the WUAs are characterized by a top-down approach; no efficient governance structures; no elections for directors and administrators and a significant lack of water users' participation in decisionmaking processes. This political-organizational approach and related features, which are quite distant from the WUAs' example sponsored by the IMT and generally by the IWRM framework (hydrographic boundaries, integration, participation, bottom-up practices), emerged in all the three districts without significant differences.

The support for a fairly executed IMT process has been partly lacking both from the water users and the state authorities; the water users, instead of self-promoting bottom-up practices, participation and support for water fee collection, have preferred water control ensured by the state organizations, albeit with lacks. The government, which gave the farmers the possibility of establishing WUAs and recognized the recent associations' failures, nowadays despite encouraging private farmers' action and new WUAs' establishment, is supporting, both financially and politically, the state enterprises. Therefore, the institutional and organizational vacuum caused by the future dismantling of the district water departments and the WUAs' failure will be probably filled by the Iujvodkhoz Republican State Enterprise both in the Ordabasy and Otrar districts. In Tyulkibas, due to the absence of primary level canals, the future water management structure is still uncertain. Hence, nowadays a political turnaround and a renewed state involvement in water control are emerging: the future mission of the Republican State Enterprise at the local level clearly shows these upcoming processes and a redefinition of water management practices in Kazakhstan.

Therefore, the evidence emerging from the case studies allows a better understanding of the complex and uncertain path of water reforms, which nowadays is moving away from the IMT implementation that is going on in Kazakhstan.

Similar issues emerged in other developing countries historically featured by a strong top-down tradition and induced by donors to implement the IWRM/IMT framework (Biswas 2008). Although the hydraulic mission (Allan 2003) in Kazakhstan has been over since two decades, the sociopolitical and economic changes required to fully implement the IMT have not occurred, leading to a reinterpretation of the concept and a subsequent re-thinking, state-oriented, of water reforms.

\section{References}

Abdolvand B, Mez L, Schutt B, Rost T, Winter K (2013) Capacity building on water management in Central Asia: expert training under the Berlin process framework. Environ Earth Sci (this issue)

Abdolvand B, Winter K, Mirsaeedi-Glossner S (2013) The security dimension of water: insights from Central Asia. Environ Earth Sci (this issue)

Abdullaev I, Mollinga P (2010) The socio-technical aspects of water management: emerging trends at grass roots level in Uzbekistan. Water 2:85-100

Abdullaev I, Rakhmatullaev S (2013) Transformation of water management in Central Asia: from state-centric, hydraulic mission to socio-political control. Environ Earth Sci. doi:10. 1007/s12665-013-2879-9

Meinzen-Dick R et al (1994) Sustainable water users associations: lessons from a literature review. In: Paper prepared for the World Bank Resources Seminar, December 13-14, 1994

Allan T (2003) IWRM/IWRAM: a new sanctioned discourse?, Occasional Paper 50, SOAS water issues study group. SOAS, King's College, University of London

Aminova M, Abdullaev I (2009) Water management in a statecentered environment: water governance analysis of Uzbekistan. Sustainability 1:1240-1265

Bichsel C (2009) Conflict transformation in Central Asia-irrigation disputes in the Fergana Valley. Routledge, London \& New York

Biswas AK (2008) Integrated water resource management: is it working? Water Resour Dev 24(1)

Burger R (1998) Water Users Associations in Kazakhstan: an Institutional Analysis. NIS project, Environment Discussion Paper no. 45

DFID-Mott-Macdonald (2003) Privatisation/transfer of irrigation management in Central Asia. Final report

Faggi P (1991) La desertificazione: geografia di una crisi ambientale. Etas, Milano

Feike T, Mamitimin Y, Li L, Abdusalih N, Doluschitz R (2013) Development of agricultural land and water use and its driving forces in the Aksu-Tarim Basin, P.R. China. Environ Earth Sci (this issue)

Ghazouani W, Molle F, Rap E (2012) Water Users Associations in the NEEN region-IFAD interventions and overall dynamics. Draft, submitted to IFAD

Groll M, Opp C, Kulmatov R, Ikramova M, Normatov I, (2013): Water Quality, potential conflicts and solutions-an upstreamdownstream analysis of the transnational Zerafshan River (Tajikistan-Uzbekistan) Environ Earth Sci. doi:10.1007/ s12665-013-2988-5

Gunchinmaa T, Yakubov M (2009) Institutions and Transitions: Does a better institutional environment make water users associations more effective in Central Asia?. Water Policy, pp 1-22

G.W.P. Technical Committee (TEC) (2009) The Dublin principles for water as reflected in a comparative assessment of institutional and legal arrangements for integrated water resources. Elanders, Stockholm. Background Papers no. 3

Hunt R (1989) Appropriate social organization? Water users associations in bureaucratic canal irrigation system. Spring, vol. 48

Janusz-Pawletta B (2013) Current legal challenges to governance of transboundary water resources in Central Asia and Joint Management Arrangements. Environ Earth Sci (this issue)

Mollinga P (2007) Water Policy-Water Politics: Social Engineering and Strategic Action in Water Sector Reform. ZEF, Working Paper Series 19, Centre for Development Research, University of Bonn

Pomfret R (2007) Rebuilding Kazakhstan's Agriculture. Central Asia Caucasus Analyst

Rakhmatullaev S, Huneau F, Celle-Jeanton H et al (2013) Water reservoirs, irrigation and sedimentation in Central Asia: a firstcut assessment for Uzbekistan. Environ Earth Sci 68(4):985-998. doi:10.1007/s12665-013-2879-9. 
Rost KT, Ebermann K, Kasymov M (2013) Irrigation in the Kochkor Rajon: major problems of Post-Soviet water management and the maintenance of irrigation systems in rural Kyrgyzstan. Environ Earth Sci

Salman MA (1997) The legal framework for water users' associations-a comparative study. World Bank Technical Paper no. 360

Sehring J (2007) The politics of water institutional reform in neopatrimonial states - a comparative analysis of Kirghizstan and Tajikistan. Dissertation, Hagen Fern University

Wegerich K (2006) Handing over the sunset: External Factors influencing the Establishment of Water users Associations in Uzbekistan: Evidence from Khorezm Province. Dissertation, Humboldt University of Berlin
Wegerich K (2008) Blueprints for water users associations' accountability versus local realities: evidences from South Kazakhstan. Water Int 33(1):43-54

Yakubov M, Ul-Hassan M (2007) Mainstreaming rural poor in water resources management: preliminary lesson of bottom-up Wua development approach in Central Asia. Irrig Drain 56:261-276

Zimina L (2003) Development water management in South Kazakhstan. In: O'Hara S (ed) Drop by drop: water management in the southern Caucasus and Central Asia. LGI Fellowship Series. Open Society Institute, Budapest, pp 87-105 